\title{
Crops behaving badly
}

\section{Are transgenic crops the reckless delinquents their critics claim?}

\author{
Dangerous Liaisons: When \\ Cultivated Plants Mate with \\ their Wild Relatives \\ by Norman C. Ellstrand \\ Johns Hopkins University Press: 2003. \\ 268 pp. \$65, £48

\section{Rick Roush}

The ecological effects of genetically modified (GM) crops remain controversial, despite evidence of the crops' agricultural benefits, such as reduced pesticide use, fewer human poisonings and increased net incomes for farmers. Their most ardent critics argue that GM crops lead to the rapid evolution of resistance in pests, harm non-target species and soil organisms, and create 'superweeds' by introducing transgenes into wild plant populations.

However, the transgenic crops that have been commercialized to date seem largely to have defied these predictions. For example, there has been no detectable increase in insects' resistance to the bacterial toxin produced as a pesticide by transgenic Bt crops. Resistance to the herbicides used with GM crops (mostly glyphosate) is still relatively minor compared to that with other widely used herbicides. The damaging effect of $B t$ crops on Monarch butterflies proved to be exaggerated, and studies on other non-target species have consistently failed to find any significant direct effects. Studies of the interactions of soil organisms and processes with GM crops have also failed to show any significant detrimental effects.

In Dangerous Liaisons, Norman Ellstrand addresses the risk of GM crops sharing their genes with wild and weedy plants - either uncultivated populations of the crop itself or closely related species. His well-written book is aimed at a wide audience of students, academics and policy-makers. The popular press seems to have a difficult time with stories about pollen flow from GM crops, typically extrapolating from studies on sunflowers, maize, canola or sugar beets to all GM crops grown anywhere. Ellstrand's book will help them identify more specific risks. The book will surely gain wide attention because of its sexy title and emphasis on GM crops, but I was more impressed by Ellstrand's documentation of the broader effects of conventional agriculture in swamping wild populations of rare plant species.

Ellstrand provides an introductory section for readers who are not population geneticists, before detailing hybridization between domesticated plants and their wild relatives, and then presenting his interpretation of these observations.

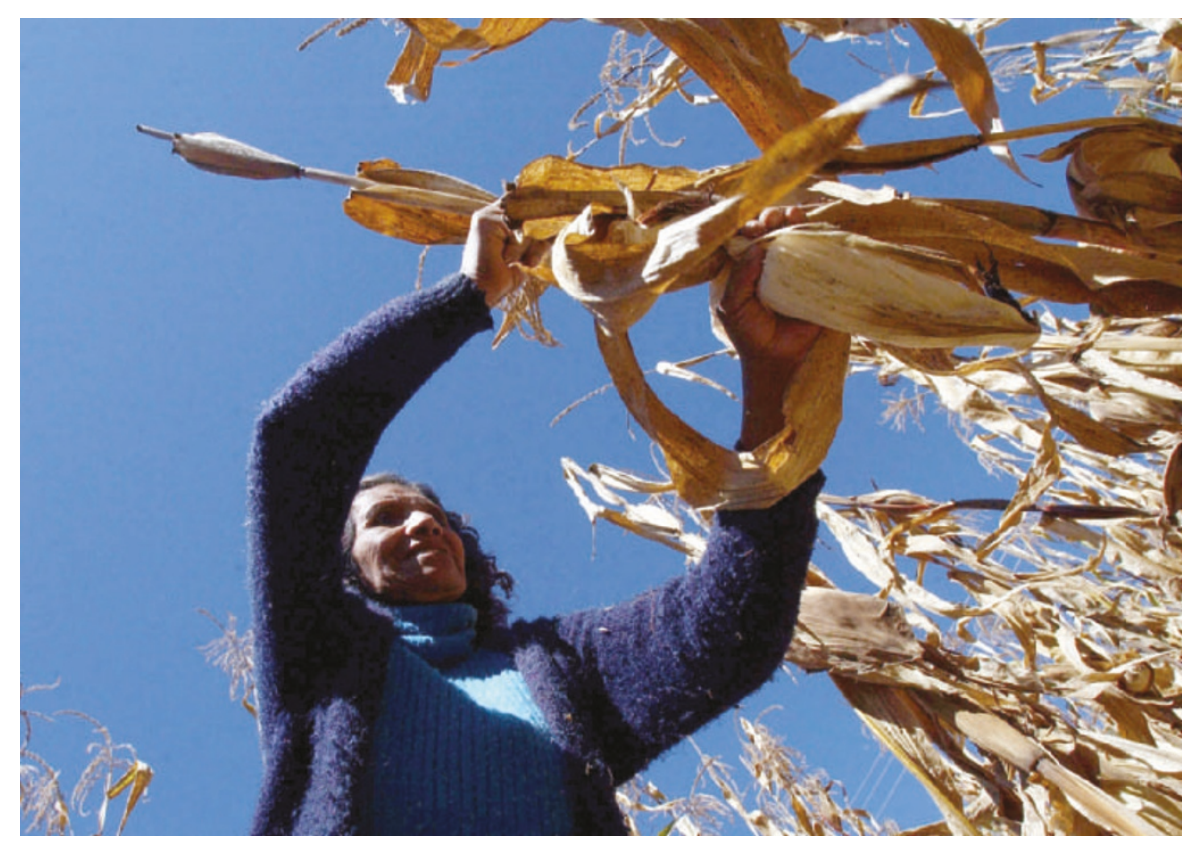

Playing the field? Hybridization between transgenic and wild maize is a potential problem in Mexico.

Despite his effort to provide this broad context for hybridization between crops and wild plants, and its consequences, I suspect that most readers will focus on chapter 7 , where Ellstrand contrasts his views with an opening quote from the Israeli plant scientist Jonny Gressel: "Most crops have no interbreeding relatives in most of the world." Ellstrand reviewed the data for the world's 25 most widely planted crops, summarized their interbreeding with wild plants in a single table, and showed that 22 of them do hybridize with wild relatives somewhere in the world. I suspect that this table will be the most widely referenced in the book, and wish that a few of the distributions were more precisely stated. For example, cotton, beans and potatoes are listed with a "multicontinental" distribution of hybridization; more precisely this refers to Latin America (and, for cotton, some islands in the Caribbean and Pacific).

But what about Gressel's proposition, especially in the context of GM crops? Using statistics from the database of the Food and Agriculture Organization of the United Nations, cited by Ellstrand (http://apps. fao.org), I checked on the dominant GM crops. At least $87 \%$ of the world's soybean crop, and $95 \%$ of the world's maize and cotton, are grown in countries for which Ellstrand lists no hybridization - and even for those countries with hybridization, such as China for soybeans, wild relatives are found in only some areas. Many of the other crops are complicated to tabulate, but Gres- sel seems to be correct that most crops are not interbreeding locally with wild relatives.

This still leaves the possibility that serious problems could arise in the few areas of the world where hybridization can occur. This currently seems possible for GM canola in Canada and the United States, and for transgenic maize that is probably growing illegally in Mexico (but has apparently escaped documentation in the refereed literature). But even after reading this book, I haven't seen any evidence of harm to human health or to the environment (including weediness) from such hybridization. Where are the superweeds that were predicted to occur from the exchange of transgenes with wild relatives?

In contrast to the lack of evidence for deleterious effects of gene flow from GM crops, there is evidence that conventional agriculture has adversely affected wild plants through genetic swamping of their populations, and that wild plants have generated weediness in crop-weed hybrids. As noted by Ellstrand, "problems associated with hybridization between conventional crops and their wild relatives received scant attention until potential gene-flow problems were described for transgenic crops". For example, hybridization with cultivated rice has been implicated in the near-extinction of an endemic Taiwanese wild rice. Hybridization of maize with its ancestor teosinte may be contributing to the extinction of teosinte populations. Indigenous cotton in the Galapagos Islands could be at risk of extinction or replacement as a result of hybridization 
with cultivated cotton. Ellstrand cites similar evidence for at least another nine species. $\mathrm{He}$ also documents in great detail the history of sugar beets in Europe, where hybrids between cultivated beets and their progenitors, the sea beets, have caused major weed problems.

Everyone interested in the effects of cropping on plant biodioversity, the evolution of weeds and the risks of GM crops should read this book. Critics and supporters of transgenic crops will continue to debate whether the relatively benign environmental and agronomic disadvantages of GM crops have been due to largely to luck or to an adequate regulatory system. Ellstrand reminds us in detail that the reliability of future successes depends on more careful risk assessment of hybridization with wild relatives.

Rick Roush is director of the University of California Statewide Integrated Pest Management Program, based at University of California, Davis, California 95616, USA.

\section{Japan's secret weapons}

\section{A Plague Upon Humanity: The Secret Genocide of Axis Japan's Germ Warfare Operation \\ by Daniel Barenblatt \\ HarperCollins: 2004. 256 pp. US\$25.95, Can\$35.95. To be published in the UK in March 2004 by Souvenir Press, £20}

\section{Alastair Hay}

When Japan invaded Manchuria in 1931, it alleged Chinese involvement in blowing up a section of the Japanese-owned South Manchurian Railway. The charge was false: confessions in 1945 by some of those involved confirmed that Japanese engineers carried out the attack to provide the pretext for the invasion of the Asian mainland. History is littered with similar pretexts.

Condemnation of Japan's invasion by the League of Nations followed relatively swiftly, prompting Japan to leave the body in 1933. Japan subsequently attacked China in 1937 and the US naval base at Pearl Harbor in 1941, and then invaded Vietnam, Malaysia and the Philippines. The brutality of the invaders has been well documented and the success of the military campaign waged by Japan is now textbook material.

Less well known are some of the means that Japan used to get its way, and biological warfare is just one of these. Daniel Barenblatt's A Plague Upon Humanity is an attempt to redress this ignorance and to provide a readable book that documents what happened. Barenblatt is bemused, asking himself how it is that the "startling" information about Japan's use of biological warfare "is not common knowledge, as is the Holocaust and the experiments of the Nazi doctors?"

A Plague Upon Humanity addresses this question, the succinct answer to which is political expediency. Following the defeat of Japan in the Second World War, Japanese scientists and doctors involved in the biological-warfare programme did a deal with the United States. The arrangement was that the United States would receive details of the programme and results of experiments, and in return the Japanese researchers would receive immunity from prosecution. The deal only became public knowledge in 1980 .

As far as the United States was concerned, the information it received was a windfall. Not only had the Japanese used plague, cholera, paratyphoid and anthrax in attacks on Chinese civilians, but they had also carried out experiments on some 3,000 people. These experiments are some of the most gruesome recorded, and many involved deliberately infecting people. Individuals primarily locals who had infringed the Japanese penal codes - were exposed to a single bacterial or viral agent and monitored. As the disease progressed, those infected (the maruta, or 'logs of wood', as they were often called) were assessed on a daily basis; official records show that some were even operated on while still alive. But none survived their ordeal - all 3,000 either succumbed to the infection or were killed and their tissue retained.

The Japanese tested at least 19 bacteria and viruses as candidates for biological warfare. Writing about this in 1947, Edwin Hill, chief of basic sciences at Camp Detrick in the United States, the main research centre for biological warfare, noted that his government had obtained the data for a "mere pittance by comparison with the actual cost of the studies". The value of the data was not in question for, as Hill observed: "Such information could not be obtained in our own laboratories because of scruples attached to human experimentation." Hill does not seem to comment on the scruples of those who use the information or who failed to prosecute the scientists for war crimes.

None of the above is new information, and most of it is retold in Barenblatt's book. Drawing heavily on already published works, particularly Factories of Death by the late Sheldon Harris and Unit 731 by Peter Williams and David Wallace, this latest addition to the literature is something of a disappointment. Barenblatt is right to be outraged about his subject matter and the fact that it still remains relatively obscure; perhaps his book will reach a wide audience and fulfil one of his aims. But for researchers in this field, his book will be a let-down. The sources of the many facts cited in the text are not referenced. Given that the material is so outrageous, it is all the more important to be scrupulous about documenting its origins.
Japan's biological-warfare programme was the brainchild of Shiro Ishii, an immunologist who inveigled his way into Japan's military hierarchy and pushed at an open door to get the funding he needed. His supporters were persuaded that biological warfare would assist Japan's imperial ambitions, enabling Ishii to set up shop in Manchuria at a centre known as Unit 731. Barenblatt demonizes Ishii, and there is much to condemn, but the actions of this rogue scientist are not new. What is missing from Barenblatt's book, and what is sorely needed, is solid evidence of the number of Chinese who died as a result of Japan's use of biological warfare in the field. Sadly, there are few Chinese scholars working in this area with access to the necessary archives.

Barenblatt refers to Chinese sources who claim that as many as 580,000 died as a result of Japan's biological warfare. The figure is said to be preliminary: the number may increase as house-to-house enquiries by investigators turn up more victims. Whether these deaths are truly attributable to the biological-warfare programme, or are the result of insanitary conditions brought about by mass population movements in war, is not clear. What is beyond dispute, however, is that Japan used biological warfare to kill many people. The more people who know this, and about those who did deals to suppress the information, the better. Alastair Hay is professor of environmental toxicology, School of Medicine, University of Leeds, Leeds LS2 9JT, UK.

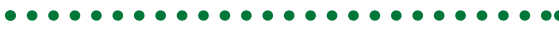 Love, actually}

\section{Why We Love: The Nature and Chemistry of Romantic Love}

by Helen Fisher

Henry Holt: 2004. \$25, 288 pp.

\section{Alison Jolly}

Tristan is on the road with Iseult, who is planning to marry his uncle, Mark. They shoot up a potion of dopamine and noradrenaline enhancer, take one look at each other and fall in love. A serotonin suppressor ensures that the passion becomes obsessive. Delirious with joy, Tristan answers an advertisement from his university at Rutgers, New Jersey, recruiting lovestruck undergraduates to have their brains scanned. In the analysis, his caudate nucleus shines out, a part of the ancient reptilian brain tuned to anticipate and discriminate between rewards. So too does his ventral tegmental area, producing ever more dopamine to drench his emotions. As Helen Fisher writes: "When I first looked at those brain scans, with the active brain regions lit up in bright yellow and deep orange, I felt the way I feel on a summer night when 